\title{
FACING A CHANGING WORLD: THERMAL PHYSIOLOGY OF AMERICAN PIKAS (OCHOTONA PRINCEPS)
}

\author{
Hans W. Otto ${ }^{1}$, James A. Wilson ${ }^{1,3}$, and Erik A. Beever ${ }^{2}$
}

\begin{abstract}
American pikas (Ochotona princeps) are of concern with respect to warming montane temperatures; however, little information exists regarding their physiological ability to adapt to warming temperatures. Previous studies have shown that pikas have high metabolism and low thermal conductance, which allow survival during cold winters. It has been hypothesized that these characteristics may be detrimental, given the recent warming trends observed in montane ecosystems. We examined resting metabolic rate, surface activity, and den and ambient temperatures $\left(\mathrm{T}_{\mathrm{a}}\right)$ of pikas in late summer (August 2011 and 2012) at 2 locations in the Rocky Mountains. Resting metabolic rate was calculated to be $2.02 \mathrm{~mL} \mathrm{O}_{2} \cdot \mathrm{g}^{-1} \mathrm{~h}^{-1}$, with a lower critical temperature (LCT) of $28.1 \pm 0.2{ }^{\circ} \mathrm{C}$. No upper critical temperature (UCT) could be determined from our data; therefore, the estimated thermoneutral zone (TNZ) was $28.1^{\circ} \mathrm{C}$ to at least $35.0^{\circ} \mathrm{C}$ (upper experimental temperature). Pikas in this study showed the same bimodal above-talus activity patterns reported in previous studies. Den temperatures in Colorado were correlated with, but consistently lower than, current ambient temperatures. Wyoming den temperatures showed a weak correlation with $\mathrm{T}_{\mathrm{a}} 20$ min prior to the current den temperature. This study is one of few to present data on the physiological response pikas may have to current warming conditions, and the first to perform metabolic measurements in situ. Our data support conclusions of previous studies, specifically MacArthur and Wang $(1973,1974)$ and Smith $(1974)$, which indicated American pikas may not have the physiological ability to cope with high $\mathrm{T}_{\mathrm{a}}$. Our results also highlight the importance of shaded regions below the talus rocks for behavioral thermoregulation by pikas.
\end{abstract}

RESUMEN.-La pica americana (Ochotona princeps) es una especie considerada de preocupación debido al aumento de la temperatura en las montañas. Sin embargo, existe poca información relacionada a su capacidad fisiológica para adaptarse a temperaturas más cálidas. Estudios previos han mostrado que las picas tienen un metabolismo alto y una conductividad térmica baja, lo que les permite sobrevivir en los inviernos fríos. Se ha planteado la hipótesis de que estas características pueden ser perjudiciales, dadas a las tendencias recientes de calentamiento en los ecosistemas de montaña. Examinamos la tasa metabólica en reposo, la actividad superficial y la temperatura en las madrigueras y la temperatura ambiente $\left(\mathrm{T}_{\mathrm{a}}\right.$ ) de las picas a finales del verano (agosto de 2011 y 2012) en 2 áreas de las Montañas Rocosas. Calculamos que la tasa metabólica en reposo sería $2.02 \mathrm{~mL} \mathrm{O}_{2} \cdot \mathrm{g}^{-1} \mathrm{~h}^{-1}$, con una temperatura crítica inferior (LCT) de $28.1 \pm 0.2^{\circ} \mathrm{C}$. No pudimos determinar la temperatura crítica superior (UCT) a partir de nuestros datos; por lo tanto, la zona termoneutral estimada (TNZ) fue 28.1 a al menos $35.0^{\circ} \mathrm{C}$ (temperatura experimental superior). Las picas en este estudio mostraron los mismos patrones bimodales de actividad por encima del talud que los reportados en estudios anteriores. La temperatura de las madrigueras en Colorado se correlacionaron con, pero siendo siempre inferiores, la temperatura ambiental actual. La temperatura de las madrigueras en Wyoming mostraron una correlación débil con la temperatura ambiente 20 minutos antes de la temperatura actual de la madriguera. Este estudio es uno de los pocos que presentan datos de las respuestas fisiológicas que las picas podrían tener en las condiciones actuales de calentamiento climático, y el primero en realizar mediciones metabólicas in situ. Nuestros datos respaldan conclusiones de estudios previos, particularmente MacArthur y Wang 1973 y 1974, y Smith 1974, que indican que las picas americanas pueden no tener la capacidad fisiológica para enfrentar las altas temperaturas ambientales y resalta la importancia de las regiones sombreadas bajo las rocas del talud para el comportamiento de termorregulación de las picas.

Across North America, mean atmospheric temperature has warmed by $0.6{ }^{\circ} \mathrm{C}$ during the past century (Houghton et al. 2001). Mirroring the rate of increasing global temperatures, effects of climate change on terrestrial organisms are predicted to escalate with increasing latitude and elevation (Deutsch et al. 2008, Beever et al. 2010). Montane systems and their wildlife, in particular, are predicted to be highly sensitive to projected climate change (Pauli et al. 1996, Moritz et al. 2008, Sekercioglu et al. 2008). For example, several regions of the Rocky Mountains may show increased snowfall combined with earlier snowmelt (Hidalgo et al. 2009, Holsinger et al. 2014), or increased summer temperatures and longer summer drought (Abatzoglou et al. 2014). Alterations in largescale climate patterns are predicted to have

\footnotetext{
${ }^{1}$ Department of Biology, University of Nebraska at Omaha, Allwine Hall 114, 6001 Dodge Street, Omaha, NE 68182-0040.

${ }^{2}$ U.S. Geological Survey, Northern Rocky Mountain Science Center, 2327 University Way, Suite 2, Bozeman, MT 59715.

${ }^{3}$ Corresponding author. E-mail: jameswilson@unomaha.edu
} 
important effects on species inhabiting highelevation ecosystems of the western United States. Many of these predictions are already observed across the Northern hemisphere, including changes in phenology (Post and Stenseth 1999), species distributions (Payette 1987, Floyd 2004, Walther et al. 2005), body size (Smith et al. 1998, Fernández-Salvador et al. 2005), reproductive output (Lewis 1993), hibernation patterns (Inouye et al. 2000, Blumstein et al. 2004), abundance (Beever et al. 2013), and community structure (Brown et al. 1997).

In response to changing climates, many species in the paleontological record and in contemporary times have migrated to new locations that mimic their original environment. In alpine systems, this often (but not always: see Crimmins et al. 2011, Rapacciuolo et al. 2014) means a shift to higher elevations or latitudes. For example, elevational range shifts have occurred in many species inhabiting the southern Sierra Nevada Mountains as a result of climate change (e.g., Moritz et al. 2008, Rowe et al. 2014). Out of 28 species of small mammals analyzed, 14 species showed an upward shift of approximately $500 \mathrm{~m}$ in elevation near Yosemite National Park (Moritz et al. 2008). Likewise, Walther et al. (2005) confirmed an accelerated trend in the upward shift of alpine plants, which are presumably altering their range in response to warmer climatic conditions. Wilson and Gutiérrez (2011) recently reviewed species' elevational range shifts worldwide, and provided thoughtful analysis on mechanisms underlying the changes. Future responses of plant and animal populations to ongoing climatic change are uncertain, and the specific physiological processes that underlie the ability of a species to respond to changes in climate are largely unknown. As a result, it is increasingly important to understand the physiology of montane species and how a changing climate may impact their distribution.

Warming trends in the past appear to have forced the American pika (Ochotona princeps) across the Great Basin to retreat to higher latitudes and elevations (Grayson 2005), which typify their current disjunct distribution across the Intermountain West (Beever et al. 2003). In addition, pikas have begun to show a pattern of localized extinction throughout sites in mountain ranges of the Great Basin reflecting climatic, anthropogenic, and biogeographic factors, with climate-induced factors continuing to strengthen their influence on pika distributions over time (Beever et al. 2003, 2011, 2013). The underlying physiological response that links pika populations to changes in climate are unknown; however, pikas might have physiological limitations with respect to high ambient temperatures $\left(T_{a}\right)$, because (1) they do not employ hibernation or seasonal migration as an energy-saving mechanism; (2) only $3{ }^{\circ} \mathrm{C}$ separates their resting $\mathrm{T}_{\mathrm{b}}\left(\bar{x}=40.1{ }^{\circ} \mathrm{C}\right.$; MacArthur and Wang 1973) from their reported upper lethal temperature $\left(\bar{x}=43.1{ }^{\circ} \mathrm{C}\right.$; MacArthur and Wang 1973, 1974, Smith and Weston 1990), which is a difference well below that of most other montane mammals; (3) they have low thermal conductance, which is as low as 53\% of the value predicted by the pika's body mass (this conductance limits their ability to dissipate heat in warm periods; MacArthur and Wang 1973); and (4) they have a high basal metabolic rate $(143 \%$ of that predicted by allometric models; MacArthur and Wang 1973). As a result, the dual pressures of maintaining warmth during winter yet not overheating during summer are challenging for pikas, given the species' physiological and life-history traits.

Across all vertebrates, endothermy permits some species to remain active in high-elevation and high-latitude climates, but only if they can afford the extra energetic costs $(\mathrm{McNab}$ 2012). Small mammals typically have higher energetic costs because of their comparatively high ratio of surface area:volume, and consequently, they exhibit more-rapid heat loss than do larger bodied species (McNab 2002). The relationship between metabolism and ambient temperature $\left(\mathrm{T}_{\mathrm{a}}\right)$ in endothermic animals is characterized by the metabolic response curve, which includes the thermoneutral zone (TNZ), a range of temperatures within which endothermic animals require no changes in metabolism to maintain their body temperature $\left(\mathrm{T}_{\mathrm{b}}\right)$. The TNZ is bounded by upper (UCT) and lower (LCT) critical temperatures, above or below which metabolism increases to compensate for further heat stress, respectively (McNab 2012). However, individuals can use conductive and/or convective heat loss to buffer their $\mathrm{T}_{\mathrm{b}}$ from ambient temperatures above their UCT. In addition to physiological mechanisms, individuals can employ behavioral responses to mitigate extreme temperatures. During high 
$\mathrm{T}_{\mathrm{a}}$, metabolic cost can be reduced by limiting exposure to solar radiation, including by limiting surface activity, seeking shade, adjusting posture, and shuttling between the burrow and surface microenvironments (MacArthur and Wang 1974, Smith 1974, Belk and Smith 1991, Vispo and Bakken 1993, Carrascal et al. 2001).

Pikas have several characteristics for surviving harsh montane winters. Their overall round body shape and small circular ears are adapted for minimizing heat loss; however, these adaptations could be disadvantageous during times of high $\mathrm{T}_{\mathrm{a}}$. For example, pikas have thick fur that insulates them against severe cold (Dearing 1997, Beever 2002). Although pikas might be susceptible to high temperatures because of physiological constraints, they mediate excessive heat gain by utilizing (subsurface) interstitial-talus habitat that is shaded, insulated, and cooler than the surface (Varner and Dearing 2014). The actual benefit of using cooler microhabitats can be measured with a combination of microclimatic and behavioral data (Carpenter 1966); thus, monitoring the microhabitat temperatures that organisms occupy can help us understand the complicated balance between physiological and behavioral responses to thermal stressors.

Our overarching objective in this research was to assess physiological responses of American pikas to ambient temperatures spanning from $10{ }^{\circ} \mathrm{C}$ to $35{ }^{\circ} \mathrm{C}$ (in increasing $5{ }^{\circ} \mathrm{C}$ increments) at 2 sites differing by approximately $1200 \mathrm{~m}$ elevation and $5^{\circ}$ of latitude. Because both increased elevation and latitude have a cooling effect on mean $T_{a}$, species can occur at increasingly lower elevations as one moves poleward (Merriam 1892; see fig. 4 of Beever et al. [2011] specifically for $O$. princeps). Accordingly, latitude-adjusted differences in $\mathrm{T}_{\mathrm{a}}$ will be much less than predicted by the approximately 1200-m difference in elevation alone, though the exact difference will reflect variability in both latitudinal and elevational lapse rates. Both rates are known to vary among seasons, across years and decades, across space (e.g., leeward vs. windward sides of mountains, continental vs. maritime climate), and across specific temperature measures (e.g., maximum vs. mean vs. minimum; daily vs. monthly vs. annual). MacArthur and Wang (1973, 1974) and Smith (1974) speculated that, given the high metabolism and low thermal conductance of pikas, they would be physiologically adapted to the cold, but at increased risk of hyperthermia from warming temperatures. Specifically, they suggested that pikas cannot physiologically regulate their body temperature; and without the ability to behaviorally thermoregulate by using cooler refuges under the talus, pikas exposed to $\mathrm{T}_{\mathrm{a}}$ $>28{ }^{\circ} \mathrm{C}$ would experience increased mortality (MacArthur and Wang 1973). The heatintolerance hypothesis suggested by MacArthur and Wang (1973, 1974) and Smith (1974) was first suggested during studies to measure the cold-adaptation of pikas, but the hypothesis has not been studied since global temperatures experienced their sharp rise. Thus, we chose to assess the pika's potential to accommodate a warming climate, and to quantify the amount of thermal refuge that interstitial spaces provide for pikas, across time and sites, under experimental warming. We chose to measure activity and microhabitat $\mathrm{T}_{\mathrm{a}}$ during late summer, because this period would represent the warmest temperatures that pikas would be exposed to within the year. We hypothesized that pikas would show a standard metabolic response curve across the range of $\mathrm{T}_{\mathrm{a}}$ that they may be exposed to in their habitat. Specifically, given findings from previous research (MacArthur and Wang 1974, Smith 1974, Beever et al. 2010), we predicted that (1) when individual pikas are experimentally exposed to incrementally increasing temperatures, the upper critical temperature (the point where individuals increase their metabolic rate to counter heat gain) will be located at a $\mathrm{T}_{\mathrm{a}}$ at or below $25-28{ }^{\circ} \mathrm{C}$; and that $(2)$ pikas will experience considerable heat stress at $\mathrm{T}_{\mathrm{a}}$ $>28^{\circ} \mathrm{C}$, resulting in decreased surface activity during hours when $\mathrm{T}_{\mathrm{a}}>28{ }^{\circ} \mathrm{C}$. Finally, given the results of Smith (1974), we hypothesized that (3) pikas at the Colorado site (approximately $3300 \mathrm{~m}$ ) would have more total abovetalus activity throughout the day (but would start above-talus activity later in the morning) than pikas at the Wyoming site (approximately $2100 \mathrm{~m}$ ), given the Colorado site's higher latitude-adjusted elevation and colder overnight and early morning $\mathrm{T}_{\mathrm{a}}$.

\section{Methods \\ Study Area}

This study was conducted at 2 locations within the Rocky Mountains: Mount Crested 
Butte, Gunnison County, Colorado, and Grand Teton National Park, Teton County, Wyoming. The study site at Mount Crested Butte in Colorado (hereafter, "Colorado") is at approximately $3324 \mathrm{~m}$ (3316-3432 m) elevation $\left(38^{\circ} 58^{\prime} 20^{\prime \prime} \mathrm{N}, 107^{\circ} 2^{\prime} 50^{\prime \prime} \mathrm{W}\right)$ and is dominated by talus and scree slopes. Surrounding the talus slope is a meadow of alpine grasses and forbs, plus a subalpine-shrub community and adjacent forest. Coniferous forest at our study site in Gunnison County is codominated by lodgepole pine (Pinus contorta), Engelmann spruce (Picea engelmannii), white fir (Abies concolor), subalpine fir (Abies lasiocarpa), and Douglas-fir (Pseudotsuga menziesii); deciduous forest is dominated by quaking aspen (Populus tremuloides). The focal talus patch is approximately $8905.3 \mathrm{~m}^{2}$ in spatial extent, west-facing, and consists of smallerdiameter boulders stacked several rocks deep. The study site immediately upslope of Jenny Lake in Grand Teton National Park in Wyoming (hereafter, "Wyoming") occurs at approximately $2200 \mathrm{~m}$ (2158-2500 m) elevation $\left(43^{\circ} 45^{\prime} 43^{\prime \prime} \mathrm{N}, 110^{\circ} 44^{\prime} 41^{\prime \prime} \mathrm{W}\right)$, and consists of a much larger talus slope surrounded by coniferous forest, shrubs, and herbaceous plants. The coniferous forest at our site in Teton County is also dominated by $P$. contorta and $A$. concolor. The focal talus patch is approximately $19,879.3 \mathrm{~m}^{2}$ in spatial extent, east to northeast facing, and consists of smaller-diameter boulders that are occasionally interspersed with soil and boulders $>2 \mathrm{~m}$ in diameter. We estimated slope at our sites from data at www.caltopo.com (i.e., the "Gradient Slope Shading" map overlay); slope was $25.8 \%$ in Colorado and $42.6 \%$ in Wyoming. We chose these locations because they have experienced a century or more of protection, which isolates pikas within their boundaries from other potentially confounding anthropogenic disturbances.

\section{Capture of Animals}

We captured pikas (Mount Crested Butte, Colorado) using open-mesh traps (Tomahawk model 201, Hazelhurst, WI), to prevent overheating. We set traps in talus on a stable rock and covered them on all sides, back, and top with additional rocks to protect trapped pikas from sun, precipitation, and predators. We baited traps with locally collected vegetation and baby carrots, opened them in early morning, and checked them every hour. All traps were closed from 12:00 to 16:00, to prevent thermal stress to captured animals.

We placed captured pikas into a cloth bag for transport to the on-site metabolic chamber. We transferred each pika to an anesthesia jar (transparent plastic jar) that had air holes to prevent $\mathrm{CO}_{2}$ from accumulating. A small, perforated container (salt shaker) containing cotton-soaked with a liquid anesthesia (isofluorane) was also placed in the jar with the pika. We placed pikas in the anesthesia jar until they first became unresponsive to movement of the jar, and then we removed them from the jar. After removal, pikas were under a light anesthesia and were not completely responsive to handling, but were not completely unconscious, either. Because we administered the anesthesia via isofluorane vapors mixed in a jar open to atmospheric gas, and because we observed considerable interindividual variability in response to isofluorane dosing, the dosage of isofluorane used on individuals was variable. Rather, we sedated each pika until its head became droopy and it was unresponsive; we strove to use the minimum amount necessary to achieve enough sedation to prevent injury during handling. Following light anesthetization, pikas were removed from the jar, weighed, sexed, and placed into the metabolic chamber after they quickly recovered from the anesthesia. We painted a small red dot (nontoxic, but long-lasting) on each pika's forehead for recapture identification, so that we used each individual only once for metabolic trials.

\section{Metabolic Response Curve}

As a result of permitting restrictions, we were only allowed to capture and handle individual pikas at the Colorado site; therefore, no metabolic measurements were conducted for Wyoming pikas. We performed trials to measure metabolic parameters (LCT, TNZ, and UCT) with a flow-through respirometry metabolic chamber (all components mentioned in this and next paragraph: Sable Systems Inc., Las Vegas, NV; Hayes and O'Connor 1999, Campbell and Hochochka 2000, Terblanche et al. 2006). We used the metabolic chamber in the field at the site of capture, and powered it with a portable generator. Measuring metabolic rates in situ usually reduces problems associated with transport and housing stress, each of which may inadvertently influence 
metabolic rates. Briefly, we removed individuals from traps and placed them into an individual acrylic respirometry chamber $(950-\mathrm{mL}$ volume chamber attached to airflow lines).

We supplied standardized airflow $(800 \mathrm{~mL}$. $\min ^{-1}$ ) to pikas inside an animal chamber via a Mass Flow Systems air pump. After airflow exits each chamber, it is directed through a computer-controlled baselining unit and multiplexor that allows air from individual respirometry chambers to enter analyzers and be recorded by a laptop computer. Air being analyzed flows into a relative humidity meter (RH-300) and then into an $\mathrm{O}_{2}, \mathrm{CO}_{2}$, and barometric pressure analyzer (Foxbox). All data (airflow rate, ambient barometric pressure, chamber relative humidity, oxygen and carbon dioxide concentration, and environmental chamber temperature) were downloaded using a UI-2 controller. Oxygen measurements are unreliable at high elevations, so we used carbon dioxide production as the measure of metabolic rate and converted $\mathrm{CO}_{2}$ into oxygen consumption using a respiratory quotient (RQ) of 0.85 (sensu McNab 2012).

Metabolic trials consisted of a 5-min baseline of ambient air, followed by a 7-min sample of the animal's metabolic chamber air, followed by a 3-min baseline, then another 7-min sample of the animal's chamber air and a final 5-min baseline (total measurement duration $=27$ min). Following a metabolic trial, we adjusted the environmental chamber to the next experimental temperature, and all individuals were allowed to acclimate for $45 \mathrm{~min}$. A coil of copper tubing was attached to air lines immediately before the animal's chamber to ensure that air entering the animal's chamber was at the same temperature as the experimentalcabinet temperature. We sequentially exposed pikas to experimental temperatures of $10{ }^{\circ} \mathrm{C}$, $15{ }^{\circ} \mathrm{C}, 20{ }^{\circ} \mathrm{C}, 25{ }^{\circ} \mathrm{C}, 30{ }^{\circ} \mathrm{C}$, and $35{ }^{\circ} \mathrm{C}$ (see Smith 1974). As a result of the strong time constraints placed on us by permitting agencies, we were forced to begin experimental temperatures at $10{ }^{\circ} \mathrm{C}$ and increase linearly to $35^{\circ} \mathrm{C}$. From an experimental design point of view, it would be better to randomly assign experimental temperature exposure; however, performing the experiment in this sequence minimized the time that individual pikas would be held in captivity. We closely monitored pikas for heat stress at experimental temperatures $>25{ }^{\circ} \mathrm{C}$ because of their re- ported lower heat tolerance (MacArthur and Wang 1974, Smith 1974). We planned to terminate any metabolic trial in which any visible sign of heat stress occurred in the pika. We provided pikas with apple slices as a source of water to prevent potential dehydration, which would confound our desire to investigate the effects of hyperthermia during metabolic trials. We noted that the apple slices from most individuals had been consumed to varying degrees, from a few nibbles to complete consumption. We assume that because each individual received an apple slice, the minimal effects that apple slices have on metabolism were standardized across all individuals. Because of the addition of apples to the metabolic chamber, however, our results do not satisfy the requirements for basal metabolic rate, and we therefore have data on resting metabolic rates. Following metabolic trials, we released all animals at their point of capture.

We analyzed data files using EXPEDATA (Sable Systems). For each recording, we used baseline concentrations of $\mathrm{CO}_{2}$ obtained from ambient airflow to calculate $\mathrm{CO}_{2}$ addition by the animal. We calculated rates of $\mathrm{CO}_{2}$ addition $\left(\mathrm{mL} \cdot \mathrm{h}^{-1}\right)$ as the product of flow rate and depletion or addition. Rates of $\mathrm{CO}_{2}$ addition were averaged across approximately 2 -min sections (linear sections of steady respiration) of both the initial and final samples from the respiration chamber, resulting in a single metabolic response value (milliliters per hour) at the given experimental temperature. We plotted metabolic rates for experimental temperatures to generate a metabolic response curve for each individual.

We calculated LCT and UCT breakpoints using piecewise linear regression analysis (Ryan and Porth 2007); we chose the breakpoint with the smallest mean square error. Piecewise linear regression analysis is an effective method for calculating a breakpoint because the function between the independent (temperature) and dependent (metabolic rate) variables change abruptly. Another common method for finding a breakpoint-linear regression-may not give the most accurate estimate of the LCT because breakpoints located between or at data points may not be considered fully (Nickerson et al. 1989). However, using the piecewise linear-regression method, multiple linear models are produced to fit the data for different ranges of 
the $x$-variable in a piecewise linear regression. Therefore, an exact breakpoint value is calculated where the slope of the linear function changes (Ryan and Porth 2007). We also tested breakpoint models for independence of residuals using a Wald $Z$ test on the autoregressive variance structure, and we tested them for normality using a Shapiro-Wilk test. Once we calculated the breakpoint, we performed linear regression tests on the TNZ and the line below the LCT to determine whether the slope of either of these individual relationships was significantly different from zero.

\section{Activity}

At sites in Colorado and Wyoming, we observed surface activity of individual pikas from 26 July 2010 to 13 August 2010, using a modified focal-animal technique (Altmann 1974). Observers positioned themselves before pikas became active, to decrease interruption of pika surface activity. We observed pikas from a distance of approximately $0-25 \mathrm{~m}$ using $7 \times 35$ binoculars, or unaided vision. We observed individuals from the time of first sighting until the individual was out of sight (i.e., no longer surface-active). Observers followed the focal animal and recorded the time that above-talus activity began and ended using a cumulative stopwatch, giving durations (in 1-s increments) for all activities during the time that individuals were observed. Pikas observable above the talus were counted as active, including individuals who quickly ran in and out of the talus, as long as the same individual could be followed. Percentage of time individual pikas were surface-active was calculated for each hour from sunrise to sunset, to provide an index of diurnal pika activity above the talus surface.

\section{Daily Thermal Profile}

To measure $\mathrm{T}_{\mathrm{a}}$ of microclimates that pikas are exposed to in Colorado and Wyoming, we placed Thermochron iButtons (model DS1922L) in waterproof plastic holders and positioned them in 2 microhabitats regularly used by pikas: surface (above talus, shaded) and dens (underneath talus, near haypiles). We placed iButtons adjacent to the haypile of an individual pika, with the surface recorder placed on the top of the rock located directly above the haypile and the den recorder dropped down (approximately $1 \mathrm{~m}$ ) into the space below the rocks containing the haypile. We attached a string to the den recorder to allow it to be retrieved from inside the talus. $\mathrm{T}_{\mathrm{a}}$ was recorded every $10 \mathrm{~min}$ for each of 5 microhabitat subsamples to provide a temperature profile throughout the day, from 26 July to 13 August 2010. We calculated mean temperature from the 5 subsamples for each time interval and used it for the temperature analysis.

To assess the relationship, if any, between den and ambient temperatures, we attempted to fit appropriate statistical time-series models for each site. Specifically, we attempted to fit a seasonal autoregressive integrated moving average (ARIMA) model to the temperature data from each site because these models allow increased flexibility while maintaining a simple linear form (Chatfield 2003, Cryer and Chan 2008). To satisfy the model assumptions of constant variance, some data were log-transformed to stabilize variance; in the remaining cases, the variance was already stable and thus no transformation was performed.

The first step in fitting a seasonal ARIMA model is to determine what differencing, if any, is required. Differencing is required to make a time-series stationary (i.e., constant mean, autocorrelation that depends only on time lag), which is a requirement of seasonal ARIMA models (Chatfield 2003, Cryer and Chan 2008). We determined the type and amount of differencing required by examining a plot of the time-series, as well as the resulting plot of the differenced data. Once we identified seasonal ARIMA models, we estimated the parameters by fitting the model to the data using the "arima" function in Program R. Maximum likelihood was used to determine the fit of all models, and once the best fit was determined, model diagnostics were performed. Once all models were determined to satisfy the requirements of a seasonal ARIMA model, we selected the best model (i.e., with highest $r^{2}$ ) from the suite of potential models. We present all data as mean $\pm 1 \mathrm{SE}$.

\section{RESUlTs}

We captured 4 pikas ( 3 males, 1 female) in 2011 and 10 (5 males, 2 females, 3 unknown) in 2012 at Mount Crested Butte, Colorado. All pikas captured were adults, except for 3 juvenile individuals (captured in 2012) whose sex 


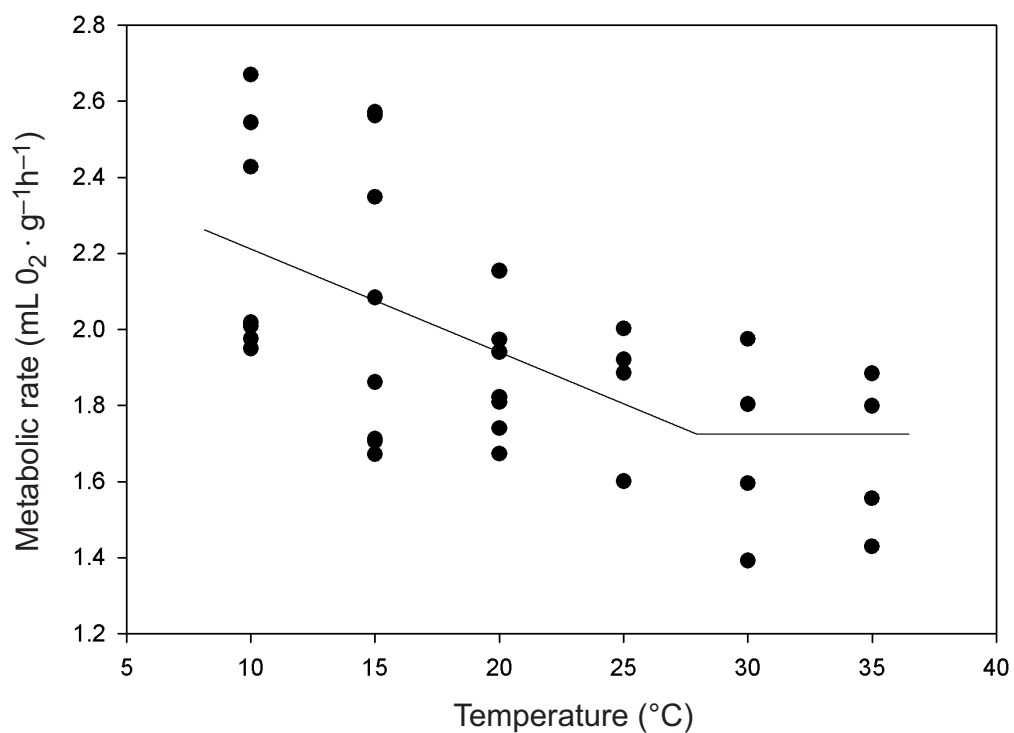

Fig. 1. Rate of metabolism in American pikas (Ochotona princeps; $n=14$ ) as a function of ambient temperatures $\left(\mathrm{T}_{\mathrm{a}}\right)$, as estimated by piecewise regression. The range in $\mathrm{T}_{\mathrm{a}}$ in which rate of metabolism is constant $\left(28.1-35.0^{\circ} \mathrm{C}\right)$ is an estimate of the thermoneutral zone, and the slope of the regression within that range did not significantly differ from a slope of zero $\left(F_{1,6}=0.02, P=0.89\right)$. Below the lower critical temperature $\left(28.1^{\circ} \mathrm{C}\right)$, metabolism increases (slope $=$ $-0.03)$ to compensate for heat loss at lower $\mathrm{T}_{\mathrm{a}}$.

we could not determine. Pikas had a mean mass of $166.8 \pm 50.0 \mathrm{~g}$ in 2011 , and $172.6 \pm$ $24.6 \mathrm{~g}$ (adults) or $111.3 \pm 37.1 \mathrm{~g}$ (juveniles) in 2012.

\section{Metabolic Response Curve}

Metabolic rate of pikas showed a standard metabolic response at lower $\mathrm{T}_{\mathrm{a}}$ (increasing metabolism below the LCT and above the UCT); however, no UCT was identified (at experimental temperatures $\leq 35^{\circ} \mathrm{C}$; Fig. 1). In the piecewise regression analysis, the best-fit breakpoint model (lowest mean squared error $=0.2275)$ had a lower critical (ambient) temperature of $28.1 \pm 0.2{ }^{\circ} \mathrm{C}$. Data in the bestfit model fit the assumptions of autoregressive independence of residuals $\left(\chi^{2}{ }_{1}=0.67\right.$, $P=0.41)$ and normality $(W=0.98, P=0.46)$. Within the thermoneutral zone, the regression of resting metabolic rate (RMR) against temperature was not significantly different from a horizontal line $\left(F_{1,6}=0.02, P=0.89\right)$. However, the portion of the metabolic response curve below the LCT had a regression whose negative slope $(-0.03)$ was significantly different from zero $\left(F_{1,24}=6.85, P=0.02\right)$. Piecewise regression analysis could not converge on a breakpoint for the UCT; therefore, no UCT could be determined by these data. As a result, the thermoneutral zone for pikas ranged from $28.1{ }^{\circ} \mathrm{C}$ to at least $35.0{ }^{\circ} \mathrm{C}$. Resting metabolic rate, estimated from the $y$ intercept of the TNZ, was $2.02 \mathrm{~mL} \mathrm{O}_{2} \cdot \mathrm{g}^{-1} \mathrm{~h}^{-1}$.

\section{Activity}

Percent of observation time that pikas were surface-active varied throughout the day. Pikas were more active during early morning and late afternoon hours, and decreased surface activity during midday (Fig. 2). In Wyoming, pikas were highly surface-active (39.8\%-45.3\% active) during morning hours (07:00-11:00), exhibited decreased surface activity $(9.5 \%-24.7 \%$ active) during midday (11:00-15:00), and resumed greater activity (25.5\%-57.6\% active) in the late afternoon (15:00-19:00). In Colorado, pika surface activity $(<35 \%$ active) was delayed in early morning (07:00-09:00) and did not reach similar morning activity levels as were observed in Wyoming until 10:00 (Fig. 2). Midday surfaceactivity levels (22.2\%-41.6\% activity) were higher in Colorado than Wyoming, and late afternoon activity levels (30.4\%-48.0\% activity) in Colorado were similar to those in Wyoming. 


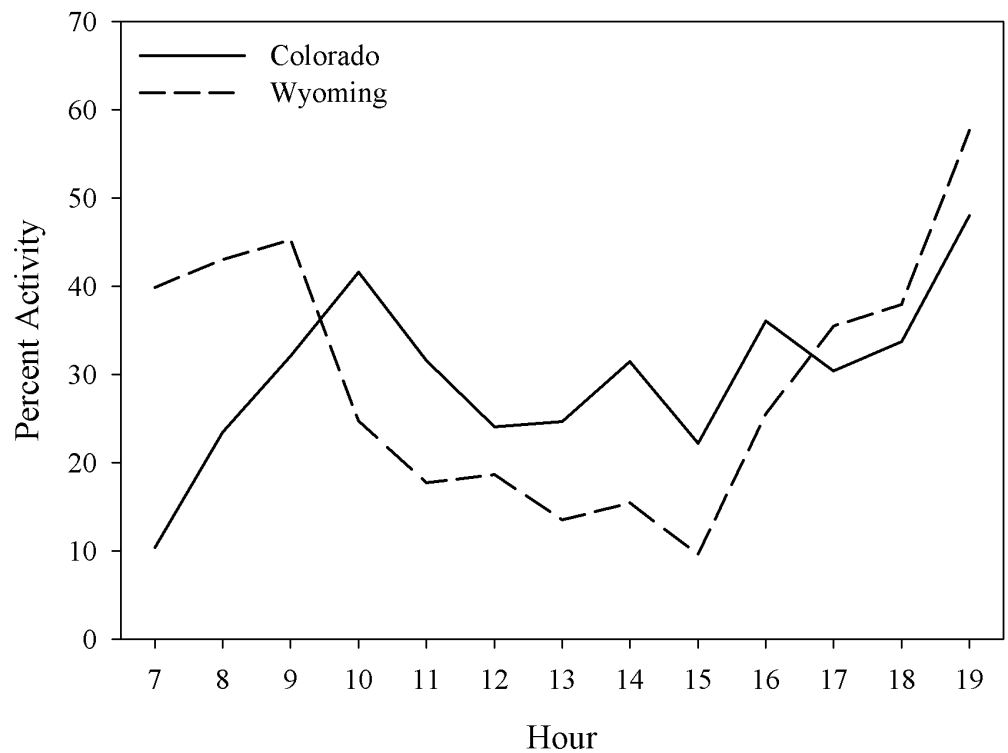

Fig. 2. Daily activity of American pikas (Ochotona princeps) above the talus at Mount Crested Butte, Colorado, and Grand Teton National Park, Wyoming, USA, during August 2011 and 2012. Percent activity was calculated for each hour block from sunrise to sunset (averaged across all individuals observed and sampling dates) to provide an index of diurnal pika activity above the talus surface.

\section{Daily Thermal Profile}

Daily $\mathrm{T}_{\mathrm{a}}$ profiles of both sites (Colorado and Wyoming) in shaded locations above the talus exhibited increasing temperatures during morning hours and reached maximum temperatures between 13:00 and 17:00 (Fig. $3)$. Although the Wyoming $\left(27.7^{\circ} \mathrm{C}\right)$ and Colorado $\left(27.1{ }^{\circ} \mathrm{C}\right)$ sites had similar maximum above-talus temperatures, those temperatures averaged above $25{ }^{\circ} \mathrm{C}$ for much longer portions of the day at the Wyoming site (from 13:30 to $19: 35$; approximately $1200 \mathrm{~m}$ elevation and approximately $5{ }^{\circ} \mathrm{C}$ farther north) than the Colorado site (from 12:30 to 13:30; approximately $3050 \mathrm{~m}$ elevation; Fig. 3). In Wyoming, temperatures in pika dens were relatively consistent throughout the day compared with temperatures above the talus. Temperatures were warmer in pika dens than on the surface during morning hours (01:00 08:00) and remained cooler than the surface during the day as $\mathrm{T}_{\mathrm{a}}$ just above the talus surface increased (Fig. 3). In Wyoming, time-series models showed that den temperatures were significantly correlated with $\mathrm{T}_{\mathrm{a}} 20$ min prior $\left(F_{1,730}=11.1, P<0.001, R^{2}=0.02\right.$; Fig. $\left.4 \mathrm{a}\right)$. However, this model was only minimally significant, suggesting that $\mathrm{T}_{\mathrm{a}}$ explains very little of the variability in den temperature. In Colorado, time-series models showed that den temperatures and ambient temperatures were closely correlated with a time lag of zero $\left(F_{1,720}=1338.0, P<0.001, R^{2}=0.65\right.$; Fig. $\left.4 \mathrm{~b}\right)$. The best-fit model for Colorado temperatures showed that den temperatures at any given time are correlated with, but lower than, the $\mathrm{T}_{\mathrm{a}}$ at that same time (Fig. 3), with mean temperature differences between $\mathrm{T}_{\mathrm{a}}$ and den reaching a maximum of $9.1{ }^{\circ} \mathrm{C}$ at $13: 00$. We observed no subsurface ice or rock-ice features (sensu Millar and Westfall 2010) at either site, although we did not excavate enough boulders to see deeper than $1 \mathrm{~m}$ below the talus surface.

\section{Discussion}

Climate change has (Cahill et al. 2012) and will continue to affect species by both direct and indirect mechanisms (Humphries et al. 2004). Ambient temperature, precipitation, soil moisture, timing of snowmelt, and relative humidity all have shown shifts across the world, and could be altered more dramatically in the near future. Each of these alone, or several factors acting synergistically, could directly 


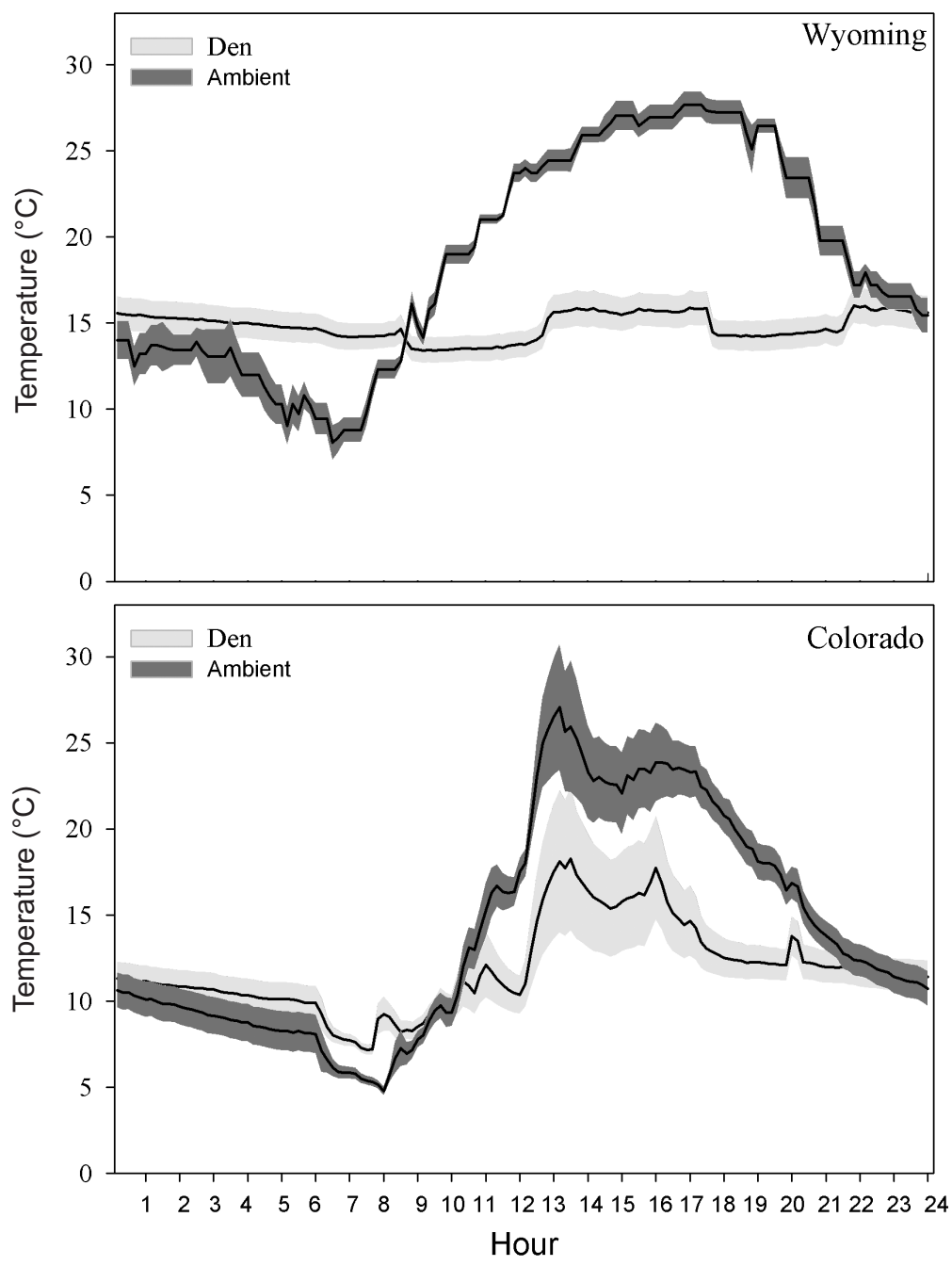

Fig. 3. Daily ambient temperatures $\left(\mathrm{T}_{\mathrm{a}}\right.$ ) profiles (averaged across 26 July 2010 to 13 August 2010) at Grand Teton National Park, Wyoming, and Gunnison County, Colorado, USA. Mean values are indicated by the dark line; \pm 1 SE is shown as dark (ambient) and light (American pika [Ochotona princeps] dens) shading. Temperatures were recorded approximately every 10 min using 5 replicate sensors within each location.

affect animal species. In addition, changes in the distribution of plants may cause variations in forage availability or quality, thus indirectly affecting certain vertebrates. It is important, therefore, to understand the relationship between organisms, their environmental requirements, and their physiological limitations. The best method for predicting changes in species distributions in a changing world is to understand links between environmental conditions, an organism's health, reproductive fitness, and population dynamics (Humphries et al. 2004). McDonald and Brown (1992) suggested that the greatest limitation of predictive models lies in their assumptions of how plants and animals respond to alterations in climate. As a result, it is critical that we understand the basic physiological requirements of species that may be affected most by alterations in climate (e.g., alpine mammals).

Increasing $\mathrm{T}_{\mathrm{a}}$ and changes in precipitation will result in new environmental pressures that will likely have notable effects on alpine species' ranges. Moreover, the magnitude of the range shifts will differ by taxa (Moritz et al. 2008, Sekercioglu et al. 2008, Rowe et al. 


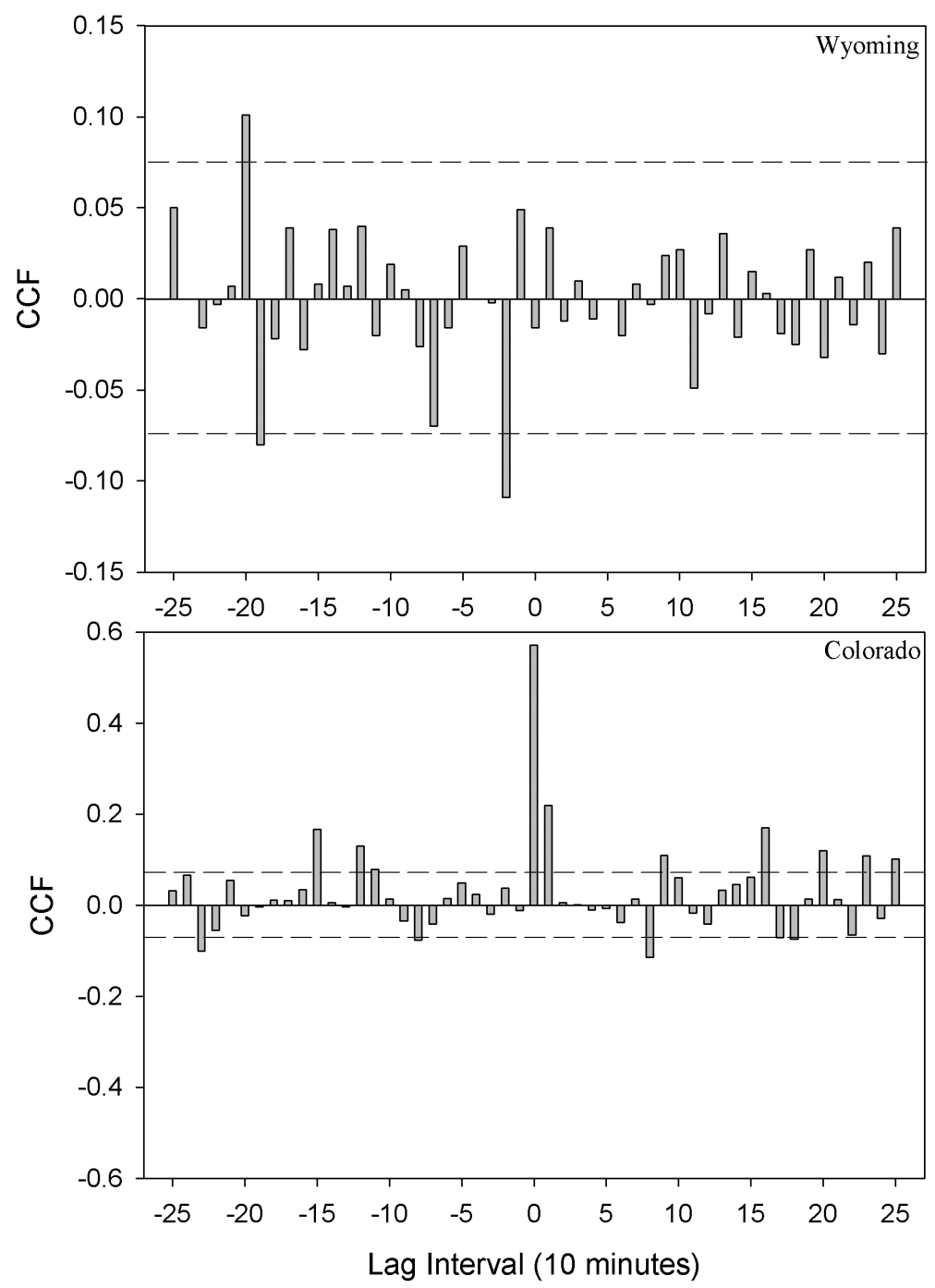

Fig. 4. Cross-correlation function (CCF) plots for American pika (Ochotona princeps) dens and ambient temperatures in Wyoming and Colorado sites. Dashed lines indicate 95\% significance levels; bars beyond the significance lines indicate a significant correlation. Time lag for den temperature, expressed in 10-min intervals, represents the interval, if any, that den temperature is correlated to ambient temperature (negative lag interval indicates ambient temperature in the past correlates to current den temperature).

2014). Generally, species well adapted to colder, high elevations (e.g., pikas) might exhibit the greatest declines (Villers-Ruiz and Castaneda-Aguado 2013), whereas eurytopic species adapted to a wider range of environmental conditions (i.e., deer mice [Peromyscus maniculatus], chipmunks [Neotamias spp.]) will likely show major changes to their distributions but may not face heavy extirpation.

The normal protocol for assessing mammalian response to thermal stress-transportation of animals to a laboratory where metabolic trials could be conducted over several days-was prohibited in this study because pikas are greatly affected by handling stress (Wunder 1992, Wilkening et al. 2013). Consequently, we could not assess whether exposure to longerduration metabolic testing would result in chronic accumulations of thermal stress. In our approach, metabolic trials began at $10{ }^{\circ} \mathrm{C}$ and increased in $5{ }^{\circ} \mathrm{C}$ increments up to $35^{\circ} \mathrm{C}$; this provided the shortest time that pikas would 
be held in captivity. Although time in captivity has been shown to increase metabolism (Studier and Wilson 1979, Warkentin and West 1990), this effect has been measured after several days to years in captivity, and is not likely to produce a significant effect within the short time $(0.45 \mathrm{~h})$ that each pika was captively held in this study. In fact, our results clearly contradicted what would be predicted from such possible confounding. When enclosed in a metabolic chamber, pikas are unable to behaviorally thermoregulate; thus, we expected to observe signs of heat stress at temperatures $>25{ }^{\circ} \mathrm{C}$, as was previously reported (Smith 1974). Signs of lethargy were observed at $25{ }^{\circ} \mathrm{C}$ in 2 individuals (both juveniles); however, after they were removed from the chamber, the individuals recovered. No further signs of thermal stress were observed in any other individuals during metabolic trials and, while in metabolic chambers, pikas were typically sedentary. Our provision of apple slices to comply with ethical concerns and requirements meant that we quantified RMR rather than basal MR, and may partly explain why our observed MRs were higher than those observed by MacArthur and Wang (1974).

There were limitations on the number of pikas we could capture; therefore, our sample size $(n=14)$ is smaller than the ideal, but is similar to the number of pikas used by MacArthur and Wang (1973; $n=16)$. In addition, because of the capture limitations, all pika individuals, regardless of sex or age, were used for our metabolic analysis. Numerous factors, including sex and body size, may confound metabolic measurements (Nagy 2005, Boratyński and Koteja 2009). For example, female voles tended to have higher metabolic rates than males (Sadowska et al. 2005); however, in a different pika species (the plateau pika, Ochotona curzoniae), neither sex nor body mass was found to significantly affect metabolic rates (Wang et al. 2006). Although increases in body mass are associated with an increase in metabolic rates (Nagy 2005), we are reporting mass-adjusted metabolic rates, which should account for the small differences in individual body mass found among our experimental animals. Although future studies should also try to obtain larger, balanced sample sizes, the great need for physiological information concerning this species suggests that, until that ideal is reached, it is important to quantify pika metabolism across genders and age classes. In fact, MacArthur and Wang (1973) used a combination of 11 adult and 5 juveniles for their metabolic calculations.

Previous studies have measured various aspects of metabolic response in a number of species and have had sample sizes ranging from below the manufacturer's (Sable Systems Inc.) recommended minimum $(n=8)$ to well above (Campbell et al. 1999, Hayes and O’Connor 1999, Kitaysky 1999, Campbell and Hochochka 2000, Knopper and Boily 2000, Mueller and Diamond 2001, Cryan and Wolf 2003, Wikelski et al. 2003, Luna and Antinuchi 2007). Sample sizes for use in measuring metabolic activity in these studies ranged from 3 to 69 individuals; however, most of these studies only measured maximal metabolic output or basal metabolic rate, and did not measure a complete response curve. Species with inherently low sample size (rare or threatened) have been used by McNab (1988) to calculate metabolic response curves and represent situations similar to the logistical restrictions placed on pikas in this study. McNab (1992) also used sample sizes of 3-14 individuals to quantify metabolic response curves in (more common) voles [Microtus spp.].

American pikas have numerous characteristics that allow them to survive through potentially harsh winters without employing hibernation. Pikas have a high rate of metabolism $\left(\mathrm{RMR}=2.02 \mathrm{~mL} \mathrm{O}{ }_{2} \cdot \mathrm{g}^{-1}\right.$ per hour, this study; $\mathrm{BMR}=1.53 \mathrm{~mL} \mathrm{O} \mathrm{O}_{2} \cdot \mathrm{g}^{-1}$ per hour, MacArthur and Wang 1974). Increased metabolism may reflect a need to produce heat to counteract heat loss associated with highlatitude and/or high-elevation habitats (Lovegrove 2003, McNab 2012). Producing heat is only one component of thermoregulation; retaining heat via decreased thermal conductance can also aid in maintaining heat during cold stress (McNab 2012). MacArthur and Wang (1973) estimated thermal conductance for pikas with a mean mass of $109.3 \mathrm{~g}$ to be between 0.24 and $0.46 \mathrm{kcal} \cdot \mathrm{g}^{-1}$ per hour per degree Celsius, whereas a typical mammal with the same mass should have a conductance of $0.46 \mathrm{kcal} \cdot \mathrm{g}^{-1}$ per hour per degree Celsius (Herreid and Kessel 1967). Increased body mass is known to reduce thermal conductance in placental mammals (Riek and Geiser 2013), primarily through mechanisms 
associated with scaling. The mean mass of pikas in our study was 59.5-63.3 g (1.54-1.58 times) heavier than the pikas used by MacArthur and Wang (1973), which might result in decreased thermal conductance values for pikas in our study. Although MacArthur and Wang (1973) reported lower conductance values for pikas, significant individual variation in conductance values could conceivably affect these generalizations. However, the typically low thermal conductance in pikas (up to $53 \%$ lower than predicted by their body mass; MacArthur and Wang 1973) indicates a high retention of metabolic heat and a decrease in energy expenditure at low $\mathrm{T}_{\mathrm{a}}$ (below their LCT), thus helping to conserve body heat and increase overwinter survival when food availability is limited. However, in increasingly warmer $\mathrm{T}_{\mathrm{a}}$, a pika's low thermal conductance may work against it (e.g., by causing it to reach hyperthermia faster than expected).

Pikas are known utilize behavioral mechanisms to moderate the effects of high $\mathrm{T}_{\mathrm{a}}$, limiting exposure to stressful temperatures by retreating to cooler refugia underneath the talus surface during periods of high $\mathrm{T}_{\mathrm{a}}$ (MacArthur and Wang 1974, Smith 1974). Pikas are typically active above the talus from just before sunrise to late morning, minimally active during the hottest hours of midday, and active again until sundown (this study; Svendsen 1979, Smith and Ivins 1986, Smith and Weston 1990). It is clear that behavioral thermoregulation plays an important part in pika thermal dynamics; however, if den temperatures rise to a level such that dens no longer act as thermal refugia, then pikas will not be able to moderate the effects of high $\mathrm{T}_{\mathrm{a}}$. This possibility is more likely in locations with shallower and less-complex talus formations that buffer $\mathrm{T}_{\mathrm{a}}$ to a lesser degree, and such pika losses have already been detected from structurally lesscomplex talus formations in areas that are near the warmer, drier edges of the species' geographic range (Ray et al. unpublished data; E. Beever personal observation).

In this study, pikas in Wyoming and Colorado were able to behaviorally moderate exposure to diurnal heat by returning to their dens underneath the talus where temperatures can be significantly lower than on the surface. In addition, the lack of metabolic response at higher $\mathrm{T}_{\mathrm{a}}$ in our metabolic data supports the original hypothesis by MacArthur and Wang
(1973, 1974) and Smith (1974) that pikas do not have the ability to physiologically adjust to high $\mathrm{T}_{\mathrm{a}}$. However, there are several possibilities that may have contributed to the lack of metabolic response at higher $\mathrm{T}_{\mathrm{a}}$ : (1) as a result of the restrictions placed on us, our metabolic trials may not have been long enough to produce hyperthermic effects at $\mathrm{T}_{\mathrm{a}}>28{ }^{\circ} \mathrm{C}$; (2) the duration of captivity was orders of magnitude shorter than in MacArthur and Wang (1973) and Smith (1974); (3) our supplying of apple slices to pikas may have ameliorated stress related to dehydration, unlike previous physiological investigations; and (4) perhaps we simply did not expose individuals to $\mathrm{T}_{\mathrm{a}}$ high enough to produce the metabolic response. It is possible that we did not use experimental temperatures high enough (>35 $\left.{ }^{\circ} \mathrm{C}\right)$ to measure the pika's UCT. However, even if pikas had a metabolic response to temperatures somewhere above $35{ }^{\circ} \mathrm{C}$, it would be biologically meaningless, because there is evidence from 2 different locations that pikas begin to experience lethal thermal stress at $\mathrm{T}_{\mathrm{a}}>28^{\circ} \mathrm{C}$ (MacArthur and Wang 1973, 1974, Smith 1974).

Neither MacArthur and Wang (1973) nor this study found an increase in metabolic rate of pikas at higher $\mathrm{T}_{\mathrm{a}}$ (i.e., $\mathrm{T}_{\mathrm{a}}>25^{\circ} \mathrm{C}$ ). We think that the observed lack of metabolic response in this study is likely due to an inability of pikas to physiologically respond to high $\mathrm{T}_{\mathrm{a}}$, and is not a spurious result associated with the shortened methodology imposed on our study. There are no studies to validate an appropriate acclimation period for measuring metabolic responses to $\mathrm{T}_{\mathrm{a}}$, and acclimation times can range from $1 \mathrm{~h}$ to weeks. As a result, there are no data to evaluate whether our methodology violates some, as yet unknown, minimum acclimation time. However, even with the shortened acclimation period, we still observed a metabolic response at $\mathrm{T}_{\mathrm{a}}<$ LCT; and if pikas were able to mount a metabolic response to high $\mathrm{T}_{\mathrm{a}}$, we should have observed a similar response.

MacArthur and Wang (1973) housed individual pikas in captivity for 1-6 mo and then acclimated and measured pika metabolism over a 3-h period. Because of the constraints placed on us, our study took place at the site of capture where we immediately measured metabolism across all experimental temperatures. Pikas in this study were allowed to 
acclimate to the new experimental temperature for $45 \mathrm{~min}$; however, it took between 30 and $60 \mathrm{~min}$ to reach the proper temperature (usually a $5{ }^{\circ} \mathrm{C}$ increase from the last experimental $\mathrm{T}_{\mathrm{a}}$ ), so pikas actually spent $75-105 \mathrm{~min}$ acclimating before metabolic measurements began. As a result, total acclimation time in this study was similar to acclimation times from metabolic studies of southern flying squirrels (Glaucomys volans; 1-h acclimation; Stapp et al. 1991), Eurasian Tree Sparrows (Passer montanus; $1 \mathrm{~h}$; Zheng et al. 2008), and phyllostomid bats (1-2 h; Almeida and CruzNeto 2011). Although our methods were not optimal, we feel that our approach nonetheless provides a valid measure of metabolic response in pikas.

If $\mathrm{T}_{\mathrm{a}}$ in montane regions continues to increase, as is predicted (IPCC 2013), interstitial talus temperatures may also increase and may reach a point where pika dens can no longer serve as a thermal refuge. Beever et al. (2010) reported strong correlation $\left(r_{a v g}=\right.$ 0.83) of temperatures within talus interstices and paired, shaded, above-talus sensors during 2005-2006 at pika sites across the hydrographic Great Basin. Interstitial temperatures were $2-11{ }^{\circ} \mathrm{C}$ cooler than above-talus temperatures during nonwinter, snow-free seasons, and remained within $2.5{ }^{\circ} \mathrm{C}$ of $0{ }^{\circ} \mathrm{C}$ despite wide swings in nearby ambient temperature during coldest weeks. Across 8 talus slopes on the eastern flank of the Sierra Nevada massif west of Mono Lake, Millar et al. (2010) reported significantly lower variability of matrix temperatures than of surface or ground temperatures, different amounts of difference between talus-matrix (i.e., interstitial) and talus-surface temperatures among seasons, and decoupled rates of change between seasons. On 4 taluses in the often rainy and foggy Columbia River Gorge, Varner and Dearing (2014) found that on taluses with $>65 \%$ moss cover, interstitial temperatures under moss varied $<1{ }^{\circ} \mathrm{C}$ within many days and strongly diverged from nearby ambient temperatures. These interstitial temperatures averaged up to $10{ }^{\circ} \mathrm{C}$ cooler in summer, and were as much as $31.5^{\circ} \mathrm{C}$ cooler, than ambient temperatures. Long-term research is needed to better understand rates of longtrend in interstitial versus ambient temperatures in more-typical pika taluses, such as those in this study.
In this study, the Colorado site is approximately $1200 \mathrm{~m}$ higher in elevation than the Wyoming site; however, the Wyoming site is approximately $5^{\circ}$ latitude north of the Colorado site. Because adiabatic cooling occurs with both increased elevation and increasingly polar latitude, the difference in ambient heating is affected both by elevation and latitude. Although there is a rule of thumb that suggests a $1{ }^{\circ} \mathrm{C}$ reduction in mean $\mathrm{T}_{\mathrm{a}}$ for every $100 \mathrm{~m}$ or $1^{\circ}$ polar latitude, we used real-world climatological data available online (Thornton et al. 2014) to calculate the actual climatological difference between our sites. Mean maximum summer $\mathrm{T}_{\mathrm{a}}$ at the Wyoming site $(23.2 \pm$ $0.1{ }^{\circ} \mathrm{C}$ ) was higher than at the Colorado site $\left(17.7 \pm 0.1{ }^{\circ} \mathrm{C}\right)$ during $1980-2014$. Summer precipitation was similar between Colorado $\left(1.7 \pm 0.1 \mathrm{~mm} \cdot\right.$ day $\left.^{-1}\right)$ and Wyoming $(1.3 \pm$ $0.1 \mathrm{~mm} \cdot$ day $\left.^{-1}\right)$; however, the Wyoming site had a winter snowpack (measured as snowwater equivalent) that was $13.2 \%$ that of the Colorado site. Both the Colorado and Wyoming sites in this study differed in the den and $\mathrm{T}_{\mathrm{a}}$ temperature profiles, with the Colorado site having den temperatures closely following $\mathrm{T}_{\mathrm{a}}$, but up to $9{ }^{\circ} \mathrm{C}$ cooler, and the Wyoming site having constant, cool den temperatures. The difference in the den thermal profiles of the 2 sites may be related to the functional combination of elevation and latitude effects, talus geometry, or vegetation cover (Varner and Dearing 2014), but more research is needed to determine the exact factors that affect temperatures below the talus.

Attempts to model range shifts, especially upslope retractions, in animal ranges have resulted in an ability to predict general trends for the near future and identify species of special concern. Considering mountaintops of the Great Basin as "sky islands" in an islandbiogeographic framework, McDonald and Brown (1992) predicted that pikas would exhibit the second-strongest magnitude of decline in mountain-range occupancy, among the 11 species they considered that were predicted to persist on at least one mountain range. In fact, Uinta chipmunks (Neotamias umbrinus; McDonald and Brown 1992), American pikas (Beever et al. 2011), and yellow-bellied marmots (Marmota flaviventris; Floyd 2004) have already begun to show a pattern of localized extinction in montane regions of the Great Basin. 
The disjunct distribution of pika populations throughout the Great Basin suggests that these populations are remnants from a time (i.e., the Wisconsonian glacial period) when temperatures were cooler and precipitation was greater (Grayson 2005). Historical records during this period indicate that Basin pikas were found approximately $783 \mathrm{~m}$ lower in elevation and have since experienced slow extirpations of low-elevation populations resulting from natural warming (Grayson 2005) and, more recently, from contemporary climate change (Beever et al. 2011). Although pika populations have been facing warming temperatures since the last glacial period, the faster rate of thermal increase observed recently may place unprecedented pressure on a species that does not typically exhibit dispersal beyond tens to hundreds of meters (Tapper 1973, Brandt 1985, but see Peacock and Ray 2001). The distribution of pikas appears to be strongly tied to variability in climate (Grinnell 1917, Hafner 1994) and is shrinking in some portions of the species' range (Beever et al. 2011, 2015, Erb et al. 2011). In addition, the American pika is strongly philopatric, and studies with tagged animals have repeatedly observed individuals often dispersing to the nearest unoccupied territories (e.g., Smith 1974, 1980). Among those individuals attempting dispersal, successful dispersal through nontalus habitat is considered to be low (Smith 1974, Peacock and Smith 1997). Although gene flow (and by extension, dispersal distances) may be greater in cooler, more mesic environments (Castillo et al. 2014), long-distance dispersal events occur quite infrequently (Hafner and Sullivan 1995, Peacock and Smith 1997).

Recent global climate models indicate that temperatures will warm more rapidly at higher elevations (e.g., IPCC 2013); additionally, these climate models agree that the western United States is predicted to exhibit particularly large magnitudes of summertime warming $\left(+3-7{ }^{\circ} \mathrm{C}\right)$ compared with other regions in North America-winters by about $+2-5{ }^{\circ} \mathrm{C}$ (Ray et al. 2010, IPCC 2013). If climate forecasts prove accurate, additional pressures from climate change may place mountain-dwelling animals in environmental conditions above their upper critical temperatures. Pikas are most likely to be vulnerable to $\mathrm{T}_{\mathrm{a}}>$ $35{ }^{\circ} \mathrm{C}$ (Fig. 1) in environmental conditions (e.g., limited heterogeneity of microclimates) where behavioral thermoregulation is insufficient, and where suitable talus habitat is unavailable at higher elevations.

\section{ACKNOWLEDGMENTS}

We are indebted to J. White, K. Hodges, and others for providing insightful editing remarks that strengthened the paper. We thank C. Effken and C. Swanson for assistance with fieldwork. S. Wolff, C. Ray, and J. Reithal provided permission and information for conducting this study and working with pikas. S. Sprott at the Rocky Mountain Biological Laboratory GIS office provided vegetation data at the Gunnison County study site. G. Bachman helped greatly with metabolic data analysis. A. Swift performed the time-series analyses. All fieldwork was conducted under an approved animal care and use protocol (08116-01-EP) from the University of Nebraska at Omaha, and met guidelines recommended by the American Society of Mammalogists (Sikes et al. 2011). Any use of trade, firm, or product names is for descriptive purposes only and does not imply endorsement by the U.S. Government.

\section{Literature Cited}

Abatzoglou, J.T., D.E. Rupp, and P.W. Mote. 2014. Seasonal climate variability and change in the Pacific Northwest of the United States. Journal of Climate 27:2125-2142.

Almeida, M.C., AND A.P. CruZ-Neto. 2011. Thermogenic capacity of three species of fruit-eating phyllostomid bats. Journal of Thermal Biology 36:225-231.

Altmann, J. 1974. Observational study of behavior: sampling methods. Behavior 49:227-267.

BeEver, E.A. 2002. Persistence of pikas in two low-elevation national monuments in the western United States. Park Science 21:23-29.

Beever, E.A., S.Z. Dobrowski, J. Long, A.R. Mynsberge, AND N.B. PiekieleK. 2013. Understanding relationships among abundance, extirpation, and climate at ecoregional scales. Ecology 94:1563-1571.

Beever, E.A., J. O’Leary, C. Mengelt, J.M. West, S. Julius, N. Green, D. Magness, L. Petes, B. Stein, A.B. NiCOTRA, ET AL. 2015. Improving conservation outcomes with a new paradigm for understanding species' fundamental and realized adaptive capacity. Conservation Letters, dx.doi.org/10.1111/conl.12190

Beever, E.A., P.F. Brussard, and J. Berger. 2003. Patterns of apparent extirpation among isolated populations of pikas (Ochotona princeps) in the Great Basin. Journal of Mammalogy 84:37-54.

Beever, E.A., C. Ray, P.W. Mote, and J.L. Wilkening. 2010. Testing alternative models of climate-mediated extirpations. Ecological Applications 20:164-178. 
Beever, E.A., C. Ray, J.L. Wilkening, P.F. Brussard, AND P.W. MотE. 2011. Contemporary climate change alters the pace and drivers of extinction. Global Change Biology 17:2054-2070.

Belk, M.C., AND H.D. Smith. 1991. Ammospermophilus leucurus. Mammalian Species 368:1-8.

Blumstein, D.T., S. Im, A. Nicodemus, and C. Zugmeyer. 2004. Yellow-bellied marmots (Marmota flaviventris) hibernate socially. Journal of Mammalogy 85: 25-29.

BORATYŃSKI, Z., AND P. Koteja. 2009. The association between body mass, metabolic rates, and survival of bank voles. Functional Ecology 23:330-339.

BRandt, C.A. 1985. The evolution of sexual differences in natal dispersal: a test of Greenwood's hypothesis. Pages 386-396 in M.A. Rankin, editor, Migration: mechanisms and adaptive significance. Contributions in Marine Science, Supplement (University of Texas) $27: 386-396$.

Brown, J.H., T.J. Valone, and C.G. Curtin. 1997. Reorganization of an arid ecosystem in response to recent climate change. Proceedings of the National Academy of Sciences 94:9729-9733.

Cahill, A.E., M.E. Aiello-Lammens, M.C. Fisher-Reid, X. Hua, C.J. Karanewsky, H.Y. Ryu, G.C. Sbeglia, F. Spagnolo, J.B. Waldron, O. Warsi, et al. 2012. How does climate change cause extinction? Proceedings of the Royal Society B Biological Sciences 282:1-10.

Campbell, K.L., and P.W. Hochochka. 2000. Thermal biology and metabolism of the American shrew-mole, Neurotrichus gibbsii. Journal of Mammalogy 81: 578-585.

Campbell, K.L., I.W. McIntyre, and R.A. MacArthur. 1999. Fasting metabolism and thermoregulartory competence of the star-nosed mole, Condylura cristata (Talpidae: Condylurinae). Comparative Biochemistry and Physiology Part A 123:293-298.

CARPENTER, R.E. 1966. A comparison of thermoregulation and water metabolism in the kangaroo rats Dipodomys agilis and Dipodomys merriami. University of California Publications in Zoology 78:1-35.

Carrascal, L.M., J.A. Díaz, D.L. Huertas, and I MozeTich. 2001. Behavioral and thermoregulation by treecreepers: trade-off between saving energy and reducing crypsis. Ecology 82:1642-1654.

Castillo, J.A., C.W. Epps, A.R. Davis, and S.A. Cushman. 2014. Landscape effects on gene flow for a climatesensitive montane species; the American pika. Molecular Ecology 23:843-856.

Chatfield, C. 2003. The analysis of time series: an introduction. 6th edition, Chapman \& Hall/CRC, Boca Raton, FL. 352 pp.

Crimmins, S.M., S.Z. Dobrowski, J.A. Greenberg, J.T. Abatzoglou, and A.R. Mynsberge. 2011. Changes in climatic water balance drive downhill shifts in plant species' optimum elevations. Science 331: 324-327.

Cryan, P.M., AND B.O. Wolf. 2003. Sex differences in the thermoregulation and evaporative water loss of a heterothermic bat, Lasiurus cinereus, during its spring migration. Journal of Experimental Biology 206: 3381-3390.

Cryer, J.D., AND K.S. Chan. 2008. Time series analysis: with applications in R. 2nd edition. SpringerScience + Business Media, LLC., New York, NY. dx.doi.org/ 10.1007/978-0-387-75959-3
Dearing, M.D. 1997. The function of haypiles of pikas (Ochotona princeps). Journal of Mammalogy 78: 1156-1163.

Deutsch, C.A., J.J. Tewksbury, R.B. Huey, K.S. Sheldon, C.K. Ghalambor, D.C. HaAk, and P.R. Martin. 2008. Impacts of climate warming on terrestrial ectotherms across latitude. National Academy of Science 105:6668-6672.

Erb, L.P., C. Ray, and R. Guralnick. 2011. On the generality of a climate-mediated shift of the American pika (Ochotona princeps). Ecology 92:1730-1735.

Fernández-Salvador, R., R. García-Perea, and J. VenTURA. 2005. Effect of climatic fluctuations on body mass of a Mediterranean vole, Microtus cabrerae. Mammalian Biology 70:73-83.

FLOYD, C.H. 2004. Marmot distribution and habitat associations in the Great Basin. Western North American Naturalist 64:471-481.

Grayson, D.K. 2005. A brief history of Great Basin pikas. Journal of Biogeography 32:2103-2111.

GrinnelL, J. 1917. Field tests of theories concerning distributional control. American Naturalist 51:115-128.

HafNer, E.R. 1994. Pikas and permafrost: post-Wisconsin historical zoogeography of Ochotona in the southern Rocky Mountains, USA. Arctic and Alpine Research $26: 375-382$.

Hafner, E.R., and R.M. Sullivan. 1995. Historical and ecological biogeography of nearctic pikas (Lagomorpha: Ochotonidae). Journal of Mammalogy 76: 302-321.

Hayes, J.P., AND C.S. O'ConNor. 1999. Natural selection on thermogenic capacity of high-altitude deer mice. Evolution 53:1280-1287.

Herreid, C.F., II, and B. Kessel. 1967. Thermal conductance in birds and mammals. Comparative Biochemistry and Physiology 21:405-414.

Hidalgo, H.G., T. Das, M.D. Dettinger, D.R. Cayan, D.W. Pierce, T.P. Barnett, G. Bala, A. Mirin, A.W. Wood, C. Bonfils, ET AL. 2009. Detection and attribution of streamflow timing changes to climate change in the western United States. Journal of Climate 22: 3838-3855.

Holsinger, L., R.E. Keane, D.J. IsaAK, L. Eby, and M.K. YOUNG. 2014. Relative effects of climate change and wildfires on stream temperatures: a simulation modeling approach in a Rocky Mountain watershed. Climatic Change 124:191-206.

Houghton, J.T., Y. Ding, D.J. Griggs, M. Noguer, P.J. van Der Linden, X. Dai, K. Maskell, and C.A. Johnson, EDITORs. 2001. Climate change 2001. The scientific basis. Contribution of Working Group I to the Third Assessment Report of the Intergovernmental Panel on Climate Change. Cambridge University Press, Cambridge, United Kingdom.

Humphries, M., M.J. Umbanhowar, and K.S. McCann. 2004. Bioenergetic prediction of climate change impacts on northern mammals. Integrative and Comparative Biology 44:152-162.

Inouye, D.W., B. Bark, K.B. ARmitage, and B.D. Inouye. 2000. Climate change is affecting altitudinal migrants and hibernating species. Proceedings of the National Academy of Science of the United States of America 97:1630-1633.

[IPCC] Intergovernmental Panel on Climate Change. 2013. Climate change 2013: the physical science basis. T.F. Stocker, D. Qin, G.K. Plattner, M. Tignor, S.K. Allen, J. Boschung, A. Nauels, Y. Xia, V. Bex, 
and P.M. Midgley, editors, Contribution of Working Group I to the Fifth Assessment Report of the Intergovernmental Panel on Climate Change. Cambridge University Press, Cambridge, United Kingdom.

Kitaysky, A.S. 1999. Metabolic and developmental responses of alcid chicks to experimental variation in food intake. Physiological and Biochemical Zoology 72:462-473.

KNOpPER, L.D., AND P. BoILy. 2000. The energy budget of captive Siberian hamsters, Phodopus sungorus, exposed to photoperiod changes: mass loss is caused by a voluntary decrease in food intake. Physiological and Biochemical Zoology 73:517-522.

LEWIS, S.E. 1993. Effect of climatic variation on reproduction by pallid bats (Antrozous pallidus). Canadian Journal of Zoology 71:1429-1433.

Lovegrove, B.G. 2003. The influence of climate on the basal metabolic rate of small mammals: a slow-fast metabolic continuum. Journal of Comparative Physiology 173:87-112.

Luna, F., And C.D. Antinuchi. 2007. Energetics and thermoregulation during digging in the rodent tucotuco (Ctenomys talarum). Comparative Biochemistry and Physiology Part A 146:559-564.

MacArthur, R.A., AND L.C.H. Wang. 1973. Physiology of thermoregulation in the pika, Ochotona princeps. Canadian Journal of Zoology 51:11-16.

MacArthur, R.A., AND L.C.H. Wang. 1974. Behavioral thermoregulation in the pika Ochotona princeps: a field study using radio-telemetry. Canadian Journal of Zoology 52:353-358.

McDonald, K.A., AND J.H. Brown. 1992. Using montane mammals to model extinctions due to global climate change. Conservation Biology 6:409-415.

MCNAB, B.K. 1988. Complications inherent in scaling the basal rate of metabolism in mammals. Quarterly Review of Biology 63:25-54.

MCNAB, B.K. 1992. The comparative energetics of rigid endothermy: the arvicolidae. Journal of Zoology, London 227:585-606.

MCNAB, B.K. 2002. The physiological ecology of vertebrates: a view from energetics. Cornell University Press, Ithaca, NY. 608 pp.

MCNAB, B.K. 2012. Extreme measures: the ecological energetics of birds and mammals. University of Chicago Press, Chicago, IL. 336 pp.

Merriam, C.H. 1892. The geographic distribution of life in North America: with special reference to the mammalia. Biological Society of Washington, Washington, DC. 64 pp.

Millar, C.I., and R.D. Westfall. 2010. Distribution and climatic relationships of the American pika (Ochotona princeps) in the Sierra Nevada and Great Basin, USA; periglacial landforms as refugia in warming climates. Arctic, Antarctic, and Alpine Research 42:76-88.

Moritz, C., J.L. Patton, C.J. Conroy, J.L Parka, G.C. White, and S.R. Beissinger. 2008. Impact of a century of climate change on small-mammal communities in Yosemite National Park, USA. Science 322:261-264.

Mueller, P., And J. Diamond. 2001. Metabolic rate and environmental productivity: well-provisioned animals evolved to run and idle fast. Proceedings of the National Academy of Science 98:12550-12554.

NAGY, K.A. 2005. Field metabolic rate and body size. Journal of Experimental Biology 208:1621-1625.
Nickerson, D.M., D.E. Facey, and G.D. Grossman. 1989. Estimating physiological thresholds with continuous two-phase regression. Physiological Zoology 62:866-887.

Pauli, H., M. Gottfried, and G. Grabherr. 1996. Effects of climate change on mountain ecosystemsupward shifting of alpine plants. World Resource Review 8:382-390.

Payette, S. 1987. Recent porcupine expansion at tree line: a dendroecological analysis. Canadian Journal of Zoology 65:551-557.

Peacock, M.M., And C. Ray. 2001. Dispersal in pikas (Ochotona princeps): combining genetic and demographic approaches to reveal spatial and temporal patterns. Pages 43-56 in J. Clobert, E. Danchin, A.A. Dhondt, and J.D. Nichols, editors, Dispersal. Oxford University Press Oxford, United Kingdom.

Peacock, M.M., AND A.T. Smith. 1997. The effect of habitat fragmentation on dispersal patterns, mating behavior, and genetic variation in a pika (Ochotona princeps) metapopulation. Oecologia 112:524-533.

Post, E., And N.C. Stenseth. 1999. Climatic variability, plant phenology, and northern ungulates. Ecology 80:1322-1339.

Rapacciuolo, G., S.P. Maher, A.C. Schneider, T.T. HamMOND, M.D. Jabis, R.E. Walsh, K.J. IKNayan, G.K. Walden, M.F. Oldfather, D.D. Ackerly, et al. 2014. Beyond a warming fingerprint: individualistic biogeographic responses to heterogeneous climate change in California. Global Change Biology 20: 2841-2855.

Ray, A.J., J.J. Barsugli, K. Wolter, and J. Eischeid. 2010. Rapid-response climate assessment to support the FWS status review of the American pika. NOAA Report for the U.S. Fish and Wildlife Service. $47 \mathrm{pp}$.

Riek, A., AND F. GEISER. 2013. Allometry of thermal variables in mammals: consequences of body size and phylogeny. Biological Reviews 88:564-572.

Rowe, K.C., K.M.C. Rowe, M.W. Tingley, M.S. Koo, J.L. Patton, C.J. Conroy, J.D. Perrine, S.R. Beissinger, AND C. Moritz. 2014. Spatially heterogeneous impact of climate change on small mammals of montane California. Proceedings of the Royal Society B 282. dx.doi.org/10.1098/rspb.2014.1857

Ryan, S.E., and L.S. PorTh. 2007. A tutorial on the piecewise regression approach applied to bedload transport data. General Technical Report RMRS-GTR189, U.S. Department of Agriculture, Forest Service, Rocky Mountain Research Station, Fort Collins, CO. $41 \mathrm{pp}$.

Sadowska, E.T., M.K. Labocha, K. Beliga, A. Stanisz, A.K. Semer, W. Jagusiak, and P. Koteja. 2005. Genetic correlations between basal and maximal metabolic rates in a wild rodent: consequences for evolution of endothermy. Evolution 59:672-681.

Sekercioglu, C.H., S.H. Schneider, J.P. Fay, and S.R. LOARIE. 2008. Climate change, elevational range shifts, and bird extinctions. Conservation Biology 22:140-150.

Sikes, R.S., W.L. Gannon, and The Animal Care and Use Committee of the American Society of MamMALOGISTS, EDITORS. 2011. Guidelines of the American Society of Mammalogists for the use of wild mammals in research. Journal of Mammalogy 92:235-253.

SMITH, A.T. 1974. The distribution and dispersal of pikas: influences of behavior and climate. Ecological Society of America 55:1368-1376. 
Sмiтh, A.T. 1980. Temporal changes in insular populations of the pika (Ochotona princeps). Ecology 61:8-13.

SMith, A.T., AND B.L. Ivins. 1986. Territorial intrusions by pikas (Ochotona princeps) as a function of occupant activity. Animal Behaviour 34:392-397.

Smith, A.T., AND M.L. Weston. 1990. Mammalian species Ochotona princeps. American Society of Mammalogists $352: 1-8$.

Smith, F.A., H. Browning, and U.L. Shepherd. 1998. The influence of climate change on the body mass of woodrats Neotoma in an arid region of New Mexico. Ecography 21:140-148.

Stapp, P., P.J. Pekins, and W.M. Mautz. 1991. Winter energy expenditure and the distribution of southern flying squirrels. Canadian Journal of Zoology 69: 2548-2555.

Studier, E.H., AND D.E. WiLson. 1979. Effects of captivity on thermoregulation and metabolism in Artibeus jamaicensis (Chiroptera: Phyllostomatidae). Comparative Biochemistry and Physiology Part A: Physiology 62:347-350.

Svendsen, G.E. 1979. Territoriality and behavior in a population of pikas (Ochotona princeps). Journal of Mammalogy 60:324-330.

TAPPER, S.C. 1973. The spatial organization of pikas (Ochotona) and its effect on population recruitment. Doctoral dissertation, University of Edmonton, Alberta. 154 pp.

Terblanche, J.S., C.J. Klok, E.S. Krafsur, and S.L. Chown. 2006. Phenotypic plasticity and geographic variation in thermal tolerance and water loss of the tsetse Glossina pallidipes (Diptera: Glossinidae): implications for distribution modeling. American Journal of Tropical Medicine and Hygiene 74: 786-794

Thornton, P.E., M.M. Thornton, B.W. Mayer, N. WiLhelmi, Y. Wei, R. Devarakonda, and R.B. Cook. 2014. Daymet: daily surface weather data on a 1-km grid for North America; version 2. Oak Ridge National Laboratory Distributed Archive Center; Oak Ridge, TN; [accessed 3 August 2015]. Available from: http:// daac.orni.gov from Temporal Range: 1980/01/01-2014/ 12/31. dx.doi.org/10.3334/ORNLDAAC/1219.

Varner, J., AND M.D. Dearing. 2014. The importance of biologically relevant microclimates in habitat suitability assessments. PLOS ONE 9(8):e104648.
Villers-Ruiz, L., and D. Castaneda-Aguado. 2013. Species and plant community reorganization in the Trans-Mexican belt under climate change conditions. Journal of Mountain Science 10:923-931.

Vispo, C.R., AND G.S. BaKken. 1993. The influence of thermal conditions on the surface activity of thirteenlined ground squirrels. Ecology 74:377-389.

Walther, G., S. Berger, and M.T. Sykes. 2005. An ecological 'footprint' of climate change. Proceedings of the Royal Society B 272:1427-1432.

WANG, J., Y. Zhang, AND D. WANG. 2006. Seasonal thermogenesis and body mass regulation in plateau pikas (Ochotona curzoniae). Oecologia 149:373-382.

Warkentin, I., AND N.H. WeST. 1990. Impact of long-term captivity on basal metabolism in birds. Comparative Biochemistry and Physiology Part A: Physiology 96: 379-381.

Wikelski, M., L. Spinney, W. Schelsky, A. Schuerlein, AND E. Gwinner. 2003. Slow pace of life in tropical sedentary birds: a common-garden experiment on four stonechat populations from different latitudes. Proceedings of the Royal Society of London 270: 2383-2388.

Wilkening, J.L., C. RaY, and K.L. Sweazea. 2013. Stress hormone concentration in Rocky Mountain populations of the American pika (Ochotona princeps). Conservation Physiology 1:1-13.

Wilson, R.J., AND D. GutiÉRREz. 2011. Effects of climate change on the elevational limits of species ranges. Pages 107-132 in E.A. Beever and J.L. Belant, editors, Ecological consequences of climate change: mechanisms, conservation, and management. CRC Press, Boca Raton, FL.

Wunder, B.A. 1992. Morphophysiological indicators of the energy state of small mammals. Pages 83-104 in T. Tomasi and T. Horton, editors, Mammalian energetics: interdisciplinary views of metabolism and reproduction. Cornell University Press, Ithaca, NY.

Zheng, W., M. Li, J. LiU, and S. Shao. 2008. Seasonal acclimatization of metabolism in Eurasian tree sparrows (Passer montanus). Comparative Biochemistry and Physiology Part A: Molecular and Integrative Physiology 151:519-525.

Received 26 January 2015 Accepted 17 August 2015 